\title{
IMPACT OF WOOD UTILIZATION ON THE FARM WOODLOT
}

\author{
By J. A. DOYLE ${ }^{1}$
}

\begin{abstract}
Greater diversification in the raw material utilization pattern has been evident during recent years. This development now focuses renewed attention on the farm woodlot which in Canada comprises vast areas of relatively accessible forests vital to the national economy. In the future, these areas of renewable resources will require that greater consideration be given to more effective programs of forest utilization and management. Log and tree quality evaluation techniques are especially important in relation to woodlot management, where the more intensive application of the quality aspect to the growing and manufacturing of primary forest products is likely to produce substantial benefits.
\end{abstract}

\section{INTRODUCTION}

Canadians often fail to appreciate the vast potential of products originating from farm woodlots across the country. Usually these woodlots are ideally located within easy reach of industrial centres where good lumber and quality forest products of special kinds can be delivered to waiting markets at low transportation costs. In 1960, the total annual value of forest products cut on farm woodlots, as reported by the Dominion Bureau of Statistics, was 49 million dollars. In terms of dollar value, this is a figure that we cannot afford to ignore.

Farm woodlots in Canada comprise a total of approximately 30 thousand square miles located predominantly in Ontario, Quebec and the Atlantic Provinces. Collectively, this area must be considered as a large and easily accessible forest that is extremely important and very vital to the economy of the nation.

\section{FOREST MANAGEMENT}

At a meeting of the Society of American Foresters held in Washington, D.C. in 1950, Ralph C. Hawley, Emeritus Professor of Silviculture, Yale University, made the following statement:

"Forest management (or silviculture) is absolutely dependent for its general practice upon utilization of the products grown in the forest. Cutting is the major tool which the forest manager must use to control the growth and development of his forest along desired lines and to obtain his annual or periodic harvest of forest products. If he is to stay in business very long he must utilize at a profit the material which he grows and cuts in his forest. Forest management can operate only on the basis of utilization of forest products."

Although directed to the forestry profession in general at that time, his advice is also extremely pertinent to the practice of forestry as it affects woodlot management both then and now.

\footnotetext{
${ }^{1}$ Assistant to Director, Forest Products Research Branch, Department of Forestry of Canada. Forest Products Research Branch Contribution No. P-38. A paper presented at the Annual Meeting of the Canadian Institute of Forestry, held in Halifax, N.S., Oct. 6-10, 1963.
} 
This concept has also been recognized by other eminent foresters both in Europe and North America, as was pointed out at the Third World Forestry Congress in Helsinki. Perhaps one of the most striking changes that has occurred recently, particularly in relation to Europe, is the recognition of the principle that the management and conservation of forests and the manufacture and distribution of forest products must be regarded as an inseparable whole. It is the primary task of the forester to grow and produce both the amounts and kinds of forest products needed by the industry and other consumers for optimum market needs compatible with the protective role of forests and the conservation of land productivity. At the same time it is the responsibility of technical research and industrial development to make possible the manufacture of the widest range of marketable products from the forest crop, and to adjust conversion methods and uses to the limitations and requirements of sound silviculture.

\section{Farm Woodlot Potentral}

These concepts, of course, have a direct relation to the farm woodlot. In the years ahead, they should have considerable impact because the farm woodlot in Canada will gain considerably in stature and importance as a provider of raw material. The greater utilization of wood, reflected by a rising demand for sawlogs and pulpwood, has created a rise in the market value of most forest products. It also should be noted that most of our easily accessible and better quality forests have been cut and that the present large commercial operations are generally in the more remote and less desirable locations. These developments have continued to focus attention on the farm woodlot and there is a new and growing realization that farm woodlot forestry and the effective utilization of woodlot raw materials is one of the more important of our forestry and forest products research problems. The efficient management and utilization of woodlots in the years ahead will, in my opinion, have an impact on Canadian forestry considerably beyond the level of present general expectations.

\section{Diversified Markets}

During the past two decades or so the increase in the number of applications for wood and wood products has been large, and as a result the annual output has steadily risen in volume and diversity. There has been great emphasis placed on the value of wood as wood fibre-how the fibres can be separated and put together again. Research continues on projects to develop uses for lignin and other component parts of the wood substance. Developments in the use of laminated wood, veneers, and plywood have made great strides in recent years, and the manufacture and use of particle boards and fibreboards in this country is, as yet, probably only in its infancy. The use of wood for pallets is rapidly increasing, and low-grade hardwoods in many areas find ready use in the rapidly expanding charcoal industry. Thus, the increased diversity of uses for wood raw material emphasizes, more than ever, the growing importance of the farm woodlot as a source of raw material.

\section{RESEARCH INCREASES UTILIZATION}

Forest products research has been active on many conversion phases, all aimed at increasing effective utilization. New processes for cooking and refining pulps to boost the yield of useful fibre are under intensive study. New methods 
are being developed to utilize species which have long been considered unsuited for the production of pulps and other materials. There is an increasing awareness of the values contained in waste liquors from chemical pulping operations. The extraction of vanillin and other chemically derived products from these liquors are notable examples of more complete utilization practices. The manufacture of wallboard, charcoal and other products from bark is under consideration, and research into the various phases of lumber conversion and manufacture has brought about marked improvements in production techniques. Processes have been developed which have brought about a large increase in the utilization of wood material formerly thought of as waste. I refer, of course, to the fact that in Canada during 1962, more than 2.7 million oven-dry tons of chips were produced from sawmill residue.

These utilization developments all, of course, have a significant effect on the value of the products of the woodlot. More diversified uses for the wood raw material naturally increase the demand as well as the value of the products produced. They also indicate that intensive management is required to keep abreast of the raw material needs of the wood industry. This can usually best be done on small management units and in this area the farm woodlot may be the answer.

\section{Wood-Based Panel Industries}

At a recent Consultation on Plywood and Other Wood-Based Panel Products held in 1963 in Rome under the auspices of the Food and Agriculture Organization of the United Nations, Dr. Egon Glesinger, former Director of FAO's Forestry and Forest Products Division, told the delegates that the world's wood-based panel industries have multiplied their output five times during the past fifteen years. This meant a growth rate of over 10 per cent per year for the entire panel industry (plywood, fibreboard and particle board), while particle board, unknown at the start of this period, is still growing at the rate of 40 per cent per year. The growth of the panel industries has for the first time in history allowed us to pour and mould wood and to transform the tree products into whatever shape we desire.

These developments and the high growth rate of the industry are of special significance to the field of forestry which, taken as a whole, as reported at the FAO Rome meeting, has tended to lag behind the pace of recent economic growth. However, there is already a manifest competition for wood raw materials from many sectors, particularly from pulp and paper, which in the future, I believe, will result in an increased dependence on the use of secondary or lower grade species, mixtures of wood species, and forest and factory residues.

\section{Log Quality Evaluation}

This enlarged demand for different classes of wood raw material products has important implications on forestry in general and on woodlot forestry in particular. In future, more attention must be paid to the quality aspects of growing and utilizing timber, and woodlot owners or managers are, in my opinion, in an excellent position to improve primary product quality. In North America the diminishing supply of high quality timber has sparked interest in the quality evaluation of the material which remains. Because of 
the wide variation in the value of the products produced from the forest, a great deal of emphasis is currently being placed on the accurate evaluation of the standing tree as to potential products contained in its bole. Such evaluation is necessary to ensure the proper channelling of veneer-quality logs to veneer mills, sawlog-quality logs to sawmills, stave-quality bolts to stave mills and so on, even down to pulpwood and wood for charcoal.

There is, however, a basic need on the part of forest managers and operators for an understanding of $\log$ quality evaluation techniques, especially in the case of hardwoods which, of course, are so common on woodlots. In log making from high-priced timber of variable quality, failure to allow for and handle intelligently all the factors affecting quality will result in a material loss. One especially vital point is the determination of the lower limits of merchantability. Today, particularly in hardwoods, it is no longer possible to base merchantability simply on size, straightness, superficial smoothness and freedom from rot and shake. Merchantability is equally influenced by type, location and concentration of log defects, including those which are so inconspicuous as to be almost unnoticeable.

Moreover, in order to utilize high value stumpage most profitably, it is generally becoming more necessary to prepare it for several markets instead of cutting for only a single end use. This means that for a given woodlot a logging operation may produce veneer logs, standard sawmill logs, tie and timber logs, logs for low grade construction lumber, stave bolts, fence posts, pulpwood and fuel wood. As foresters, I feel we have a special need to understand methods of log quality evaluation. For example, a forester marking timber under a program designed not only to feed the proper raw material to individual industries but also to maintain and improve the woodlot growing stock must know thoroughly all the factors on which quality is judged.

\section{FPRB Research Contributions}

The Forest Products Research Branch of the Department of Forestry of Canada, during recent years, has conducted a considerable amount of research on $\log$ quality evaluation techniques in an effort to provide the means of properly evaluating $\log$ and timber quality. In these studies, quality has been defined generally as that property or group of properties exhibited by $\log$ or tree that makes it physically suitable for conversion into end products for a given end use. High, medium and low quality, then, refers to logs and trees that have combinations of those properties such that they can be converted into end products with the most, the average, or the least advantage, respectively, in the broad use-class of that particular product.

It is necessary to make a distinction between classifying logs and evaluating them for quality. Classifying refers to the placement of logs or trees in groups (or use-classes) on the basis of whether or not they can be physically converted into a given type of end product. Log quality evaluation refers to a further segregation of the logs or trees within a use-class into quality groups or grades.

Log quality evaluation techniques are especially important in relation to woodlot management because, not only do these techniques provide the means of establishing measures of quality for which there are actual advantages to the owner in terms of dollars and cents, but they also may be profitably used 
in the effective up-grading of felled material. In other words, the principles of log quality evaluation can serve as a guide to woodlot owners enabling them to obtain the best possible material from the tree. The time taken to implement a program of quality control through bucking for quality will result not only in greater profits, but will bring about a sounder policy of forest utilization. In fact, it is difficult to manufacture logs and other primary forest products efficiently without taking into consideration systems of quality evaluation.

\section{IMPRoved Production Techniques}

Forest products research will continue to produce findings which will lead to the wider use and marketability of the products of the forest. Improved production techniques and more effective utilization practices will increase requirements for forest products raw materials of many kinds. The development of better methods of quality control and improved machinery have already led to significant reductions in manufacturing residues. Improved technology has made it possible to convert, into merchantable lumber, logs that would have been rejected a decade or so ago. In many cases the use of automatic equipment and better plant layout has substantially improved the lumber manufacturing process. Comparable technological improvements have also been made in connection with the manufacture of many other forest products such as pulp and paper, veneer and plywood, fibreboard and particle board. These utilization developments have unquestionably had a significant effect on woodlot forestry and undoubtedly will continue to do so in the future.

\section{CONCLUSIONS}

The woodlot, located as it is in relative general proximity to the larger forest products markets, is in a favourable position to meet the expected demand of the future. In this connection, it should be noted that the woodlots collectively comprise the largest accessible forests of the land. As such, they should be important suppliers of raw material in a relatively favourable position from a competitive standpoint.

To reach their potential, there is a need for sound principles of forest management to be used consistent with utilization requirements. The recent interest by large industrial concerns in woodlot management is encouraging as is the recognition being placed on the woodlot by various levels of government and the universities. This, of course, has been reflected through various extension programs and woodlot training schemes, as well as through the program of the Agriculture Rehabilitation and Development Act (ARDA). However, at present there is a need for more emphasis to be placed on the quality aspect of growing and manufacturing woodlot forest products, as well as on the more intensive application of the principles of woodlot management. The use of these techniques can only contribute to the economic improvement and wellbeing of the many communities which they serve.

(See illustrations on page 82 ) 
FORESTRY CHRONICLE



A hardwond stand on a farm woodlot near Ottawa.

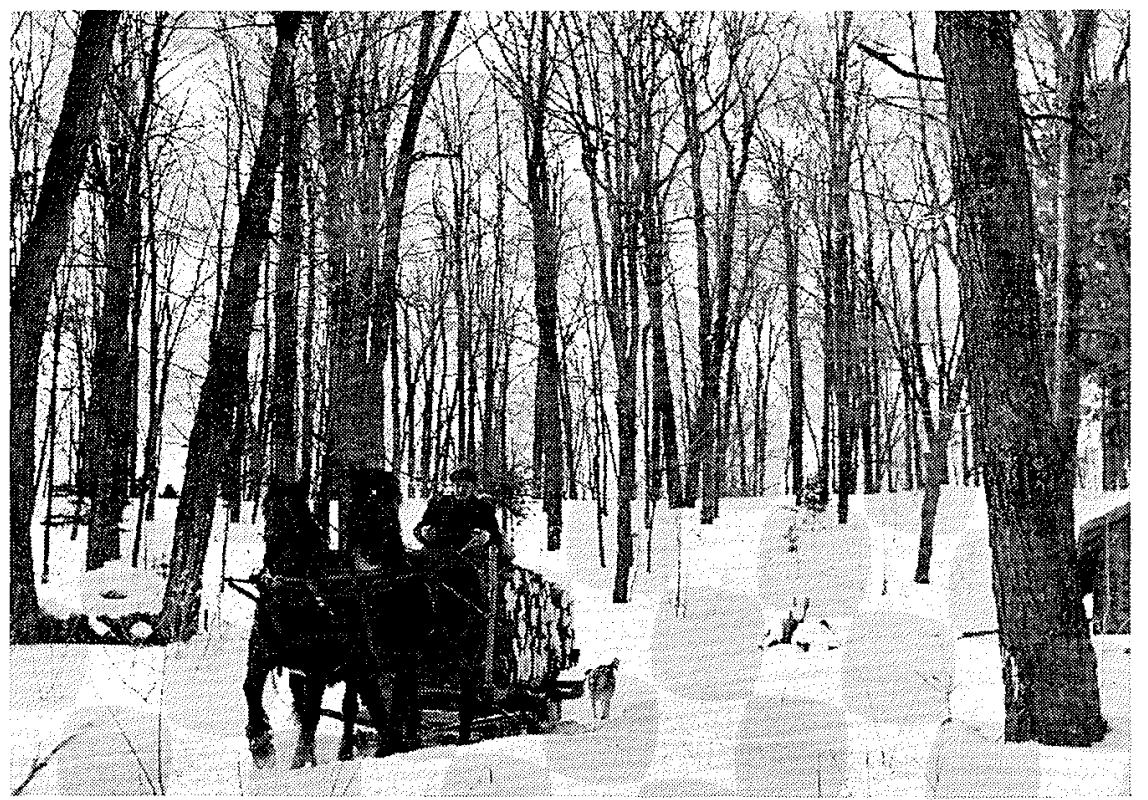

Substantial quantities of pulpwood are harvested annually from farm woodlots. 